\title{
Studies on Drying of Osmotically Dehydrated Apple Slices
}

\author{
Vikas Paradkar* and Gourav Sahu \\ College of Agricultural Engineering, Bapatla, India \\ *Corresponding author
}

\section{A B S T R A C T}

The present study was carried out to investigate the effect of solution concentration, immersion time, process temperature and slices thickness on osmotic dehydration of apple

\section{Keywords}

Osmotic dehydration,

Water loss, Solid gain,

Weight reduction,

Drying

Article Info

Accepted:

07 October 2018

Available Online:

10 November 2018 slices. The osmotic dehydration characteristics such as water loss (WL), weight reduction (WR) and solid gain (SG) were studied for sugar solution of (50 and $70^{\circ}$ Brix) at a temperature of $\left(30{ }^{\circ} \mathrm{C}\right.$ and $\left.50{ }^{\circ} \mathrm{C}\right)$ for 8 hours of immersion time. After osmotic dehydration, the apple slices were dried in tray dryer for 8 hours at $50{ }^{\circ} \mathrm{C}$ and $60{ }^{\circ} \mathrm{C}$ temperature. During osmotic dehydration, the maximum value of WL, WR, and SG was found to be $62.9 \%, 52.0 \%$, and $11.2 \%$ for $70{ }^{\circ} \mathrm{B}$ sugar solution whereas the minimum value was $52.9 \%, 41.21 \%$ and $10.50 \%$ for $50{ }^{\circ} \mathrm{B}$ solution respectively at $50^{\circ} \mathrm{C}$ after $8 \mathrm{~h}$ of osmosis. The drying rate was faster at $60{ }^{\circ} \mathrm{C}$ drying temperature for all the sizes osmotically treated apple slices as compared to $50^{\circ} \mathrm{C}$ drying temperature. This study concludes that several factor such as solution concentration, temperature and immersion time affected affects the osmotic dehydration characteristics. By using the combination of osmotic dehydration followed by drying the losses during storage and handling can be minimized and self-life of the apple fruits could be increased.

\section{Introduction}

The apple (Malus domestica) is a nutrient rich fruit, widely grown in the temperate regions with varied texture, colour, shape and size. India and China is the largest producer of apple. Apple is consumed in raw as well as processed fruits. Apple can be processed into many products such as fruit leather, candy, fruit bar, and dehydrated slices. Many traditional techniques are used for preparation of dehydrated products which are not much satisfactory from quality point of view. In India every year about $20-40 \%$ percent of the fruit and vegetable are waste due to improper transportation, inadequate processing and handling and lack of adequate storage system. Due to moisture losses and spoilage, harvested apple fruits should be marketed, processed or preserved as early as possible. Hence it is very important to convert the apple into other form such as dried product, or to develop a method for preservation and processing, to increase the self-life and quality. The preservation of food product is done to enhance the self-life of without affecting the appearance, colour and maintaining the physical and chemical properties. In fruit and vegetable preservation is usually carried out to slowdown the growth of the bacteria, fugues and other microorganism which cause spoilage. The 
many techniques are used for preservation of fruits and vegetable which includes drying, dehydration, combination of both and chemical treatment methods.

Osmotic dehydration is one of the potential preservation techniques which produce high quality products. It is the phenomenon of partial removal of water from cellular material such as fruits and vegetables. In food processing industries the osmotic dehydration is used for removal of moisture from fruit and vegetable because it maintained the flavor, color, texture and enhance self-life of final product (Gouravsahu et al., 2017, Sutar, and Gupta 2007; Pokharkar, 2001; Karthanos et al., 1995). The several process parameter influences the removal of water and addition of solid, which includes solution concentration, temperature, immersion time, type of osmotic agent, sample to solution ratio and agitation rate (Pokharkar, 2001). Osmotic dehydration method is used as a pre-treatment to several processes such as freeze drying, vacuum drying, air drying and freezing, (Dixon et al., 1976). During osmotic dehydration process, water flows from material to the osmotic solution, whereas osmotic solute is transferred from solution to the material. Osmotic dehydration is preferred because it retains color, aroma, nutritional constituents and flavor compound.

Drying is the process of removal of the moisture or water to desired and predefined level without affecting the loss of taste, flavor, colour and nutrients (Singh and Kumar, 1984). Drying of apple extent the self-life, increase market value, easy to store as well as decreases losses during storage. The microorganisms responsible for food spoilage are prevent by moisture removal. The removal of moisture from fruits and vegetable can be accomplished by drying or dehydration methods. Drying and dehydration are carried out to reduce the moisture content of the product certain level so that growth of food spoilage microorganism can be prevent and at the same time high nutritive value is maintained. Apples are rich in water content, approximately $85 \%$ (w/w) and it is possible to dehydrate and dried apples to enhance self-life by maintaining good texture, high sugar content and acidity and nutritional value. The direct drying of apples by conventional tray drying, cabinet or vacuum drying method cause change in texture, colour, flavour and nutrition loss in product. Pre-drying treatments, such as partial dehydration of fruit are suggested to improve the quality of dried product. Hence combination of osmosis and drying could be used to enhance the self-life and quality of dried apple fruit without affecting the colour, texture, flavour and nutritive value. This study was carried out to investigate the effect of osmotic solute, solution concentration on dehydration of apple slices at different temperature and immersion time further followed by drying. The drying characteristics of osmotically treated apple were also studied.

\section{Materials and Methods}

\section{Preparation of sample}

The fresh Maharaji apple fruit were procured from the market of Bapatla, Andhra Pradesh, India. The initial moisture content was approximately $85 \%$. The apples were washed in running tap water and drained under shed. The washing was carried out to remove adhering dust, dirt, impurities and surface microorganism as well as to remove fungus, insects and other pest from fruit surface. The apple slices were prepared by chopping the fruit with the help of knife or slicer in a different thickness of $5-15 \mathrm{~mm}$. The initial moisture content of raw fresh apples were determined by oven drying method. The osmotic solutions of different concentration of sugar (50, 60 and $70^{\circ}$ Brix) were prepared by 
dissolving required and calculated quantity of sugar with distilled water. The apple slices of different thickness $(5-15 \mathrm{~mm})$ were weight approximately $100 \mathrm{~g}$ for each treatment and then immersed into the osmotic solution of different concentration. The ratio of osmotic solute to apple slices was $2: 1$ on weight by weight basis were maintained.

Experimental procedure for osmotic dehydration and drying

Osmotic dehydration is a suitable step to reduce the water content of food material such as fruit and vegetable. The prepared apple slices of different thickness $(5-20 \mathrm{~mm})$ of approximately $100 \mathrm{~g}$ weight were immersed in sugar osmotic solution of different concentration (50 and $70^{\circ}$ Brix) and were placed at different temperature of $\left(30^{\circ} \mathrm{C}\right.$ and $50^{\circ} \mathrm{C}$ ). The osmotic dehydration was done in apples by using water bath arrangement at different temperature and different concentration of sugar syrup. Each sample was taken out from the container at hourly interval up to 8 hour and were immediately rinsed with water and placed in tissue paper to remove excess solution and moisture from surface. Finally the sample were weight and moisture content, water loss and solute gain for all the samples were measured at every hours. After osmotic dehydration the treated samples were weighed. The weighed apple samples were spread in the form of thin layer on aluminum trays. These aluminum trays were put in tray dryer at a temperature of $60^{\circ} \mathrm{C}$ for $8 \mathrm{~h}$. The process flow chart of drying of osmotically dehydrated apple slices is shown in Figure 1.

\section{Determination of moisture content of apple fruit slices}

Moisture content of raw and osmotically dehydrated apple slices was measured by using oven dry at $65^{\circ} \mathrm{C}$ for $24 \mathrm{~h}$ (Ranganna,
2000). Moisture content of samples is measured based on drop in weigh from initial weigh of sample. It is expressed in wet basis and dry basis by equation 1 and 2 respectively.

$$
=\underset{\substack{\text { Moisture content } \\=}}{\text { (initial weight-final weight) }}(\%
$$

Moisture content on (\% $\quad$ DB $)$ $=\frac{\mathrm{MC}(96 \mathrm{wwb})}{100-\mathrm{MC}(96 \mathrm{wb})} \times 100 \ldots$...eq. (2)

\section{Determination osmotic dehydration characteristics of apple slices}

The osmotic dehydration is characterized by solid gain, water loss and the weight reduction from solute to solution during osmosis. The net exchange in solute and water between product and osmotic solution indicate the total mass transfer during osmosis.

\section{Water loss (WL)}

The amount of water removed by fruit slices during osmosis is known as the total water loss

It is estimated on the basis of net weight loss from apple slices during osmosis (Hawkes and Flink, 1978).

$\mathrm{WL}=\frac{\mathrm{WixXi}_{\mathrm{i}}-\mathrm{Wt} \times \mathrm{Xt}}{\mathrm{Wi}} \times 100$

\section{Solid gain (SG)}

The diffusion of solute and solution is takes place which cause the adding of solid and removal of water by apple slices. The loss of water from apple slices leads to increase in solid content during transfer phase. Solid gain is the net amount of solid uptake by apple slices during osmotic dehydration and it is expressed on initial weight basis.

$\mathrm{SG}=\frac{\mathrm{wt}(1-\mathrm{Xt})-\mathrm{Wi}(1-\mathrm{Xi})}{\mathrm{wi}} \times 100$ 


\section{Weight reduction (WR)}

Weight reduction is the total exchange of solid and liquid from the sample during osmotic dehydration and will affect the final weight of the sample.

It is determine by the following formula

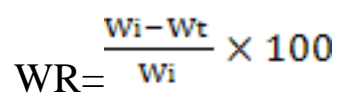

or

$\mathrm{WR}=\mathrm{WL}-\mathrm{SG}$

Where,

$\mathrm{WL}=\mathrm{Water}$ loss in percentage

$\mathrm{SG}=$ Solid gain in percentage

$\mathrm{W}_{\mathrm{t}}=$ Mass of apple slices after time $\mathrm{t}, \mathrm{g}$

$\mathrm{X}_{\mathrm{t}}=$ Water content as a fraction of mass of apple slices at time $\mathrm{t}$

$\mathrm{W}_{\mathrm{i}}=$ Initial mass of apple slices, $\mathrm{g}$

$\mathrm{X}_{\mathrm{i}}=$ Water content as a fraction of initial mass of apple slices.

Drying of osmotically dehydrated apple slices

The fruit slices were dipped in the desired syrup solution for 8 hours.

After that they were removed from the solution and gently washed to remove the adhering sugar syrup to the slice.

Osmotically dehydrated apple slices were dried in dryer at different temperature (50and $60^{\circ} \mathrm{C}$ ) and the moisture content and reduction in weight were recorded at hourly interval.

\section{Results and Discussion}

Effect of osmotic solutes concentrations on osmotic dehydration of apple slices

The solution concentrations are the important factors which affect SG, WR and WR by apple slices. WL, WR and SG by the apple slices with different sugar solution concentration of (50 and $70{ }^{\circ} \mathrm{Brix}$ ) with time are shown in the Figure 2. It is observed from the Figure 2 that WL, WR and SG by apple slices were increases with increase in sugar concentration with respective immersion time. The maximum value of WL, WR and SG was found to be $62.9 \%, 52.0 \%$, and $11.2 \%$ for 70 ${ }^{\circ} \mathrm{B}$ solute concentration whereas the minimum value of was reported to $52.9 \%, 41.21 \%$ and $10.50 \%$ for $50^{\circ} \mathrm{B}$ solute concentration respectively after 8 hour of immersion time. With increase in immersion time during osmosis at same sugar concentration the WL, WR and SG were also increases this indicate that immersion time have significant effect on osmotic process. For first 1 hour, there was not much difference in WL, WR and SG but after 1 hour, the WR was found to increase more rapidly in slices dipped in $70^{\circ} \mathrm{B}$ solution as compared to those dipped in $50^{\circ} \mathrm{B}$.

\section{Effects of immersion temperature on osmotic dehydration of apple slices}

The effect of temperature change on osmotic dehydration is shown in Figure 3. From the data obtained by study, it was found that moisture content decreases as temperature of solution increases with given osmotic time for similar concentration. This conclude that the change in temperature affect the mass transfer rate. As the temperature increases the SG as well as WL also increases for given osmotic time and solution. The maximum WL and WR was found to $38.07 \%$ and $29.1 \%$ at $50{ }^{\circ} \mathrm{C}$ whereas lowest value was $28.5 \%$ and $15.5 \%$ respectively at $30{ }^{\circ} \mathrm{C}$ after 8 hour of osmotic dehydration of apple slices. 
Fig.1 Process flowchart of drying of osmotically dehydrated apple slices

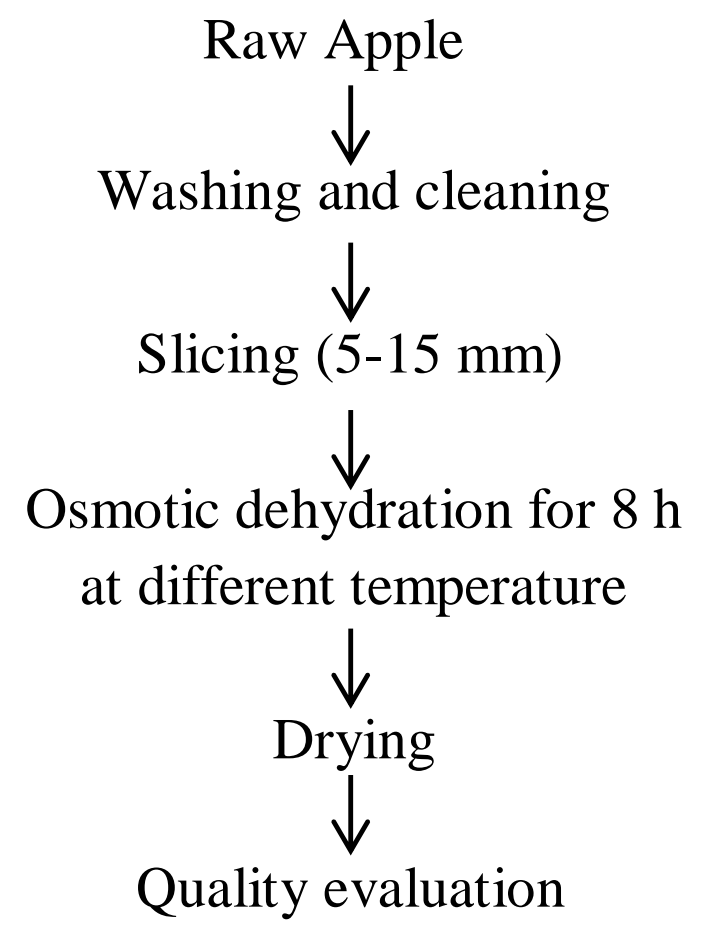

Fig.2 Effect of solute concentration on osmotic dehydration of apple

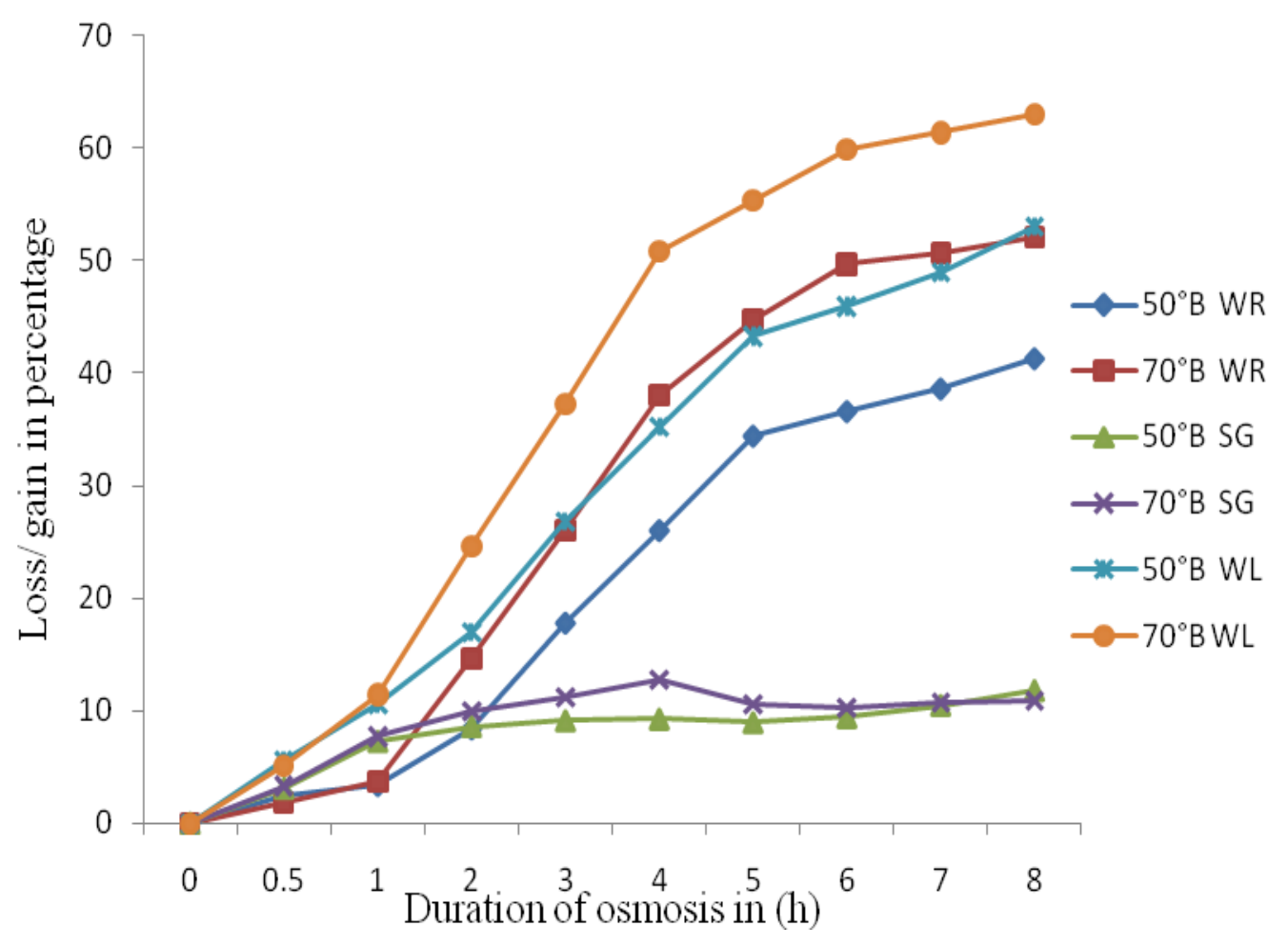


Fig.3 Effect of process temperature on osmotic dehydration of apple

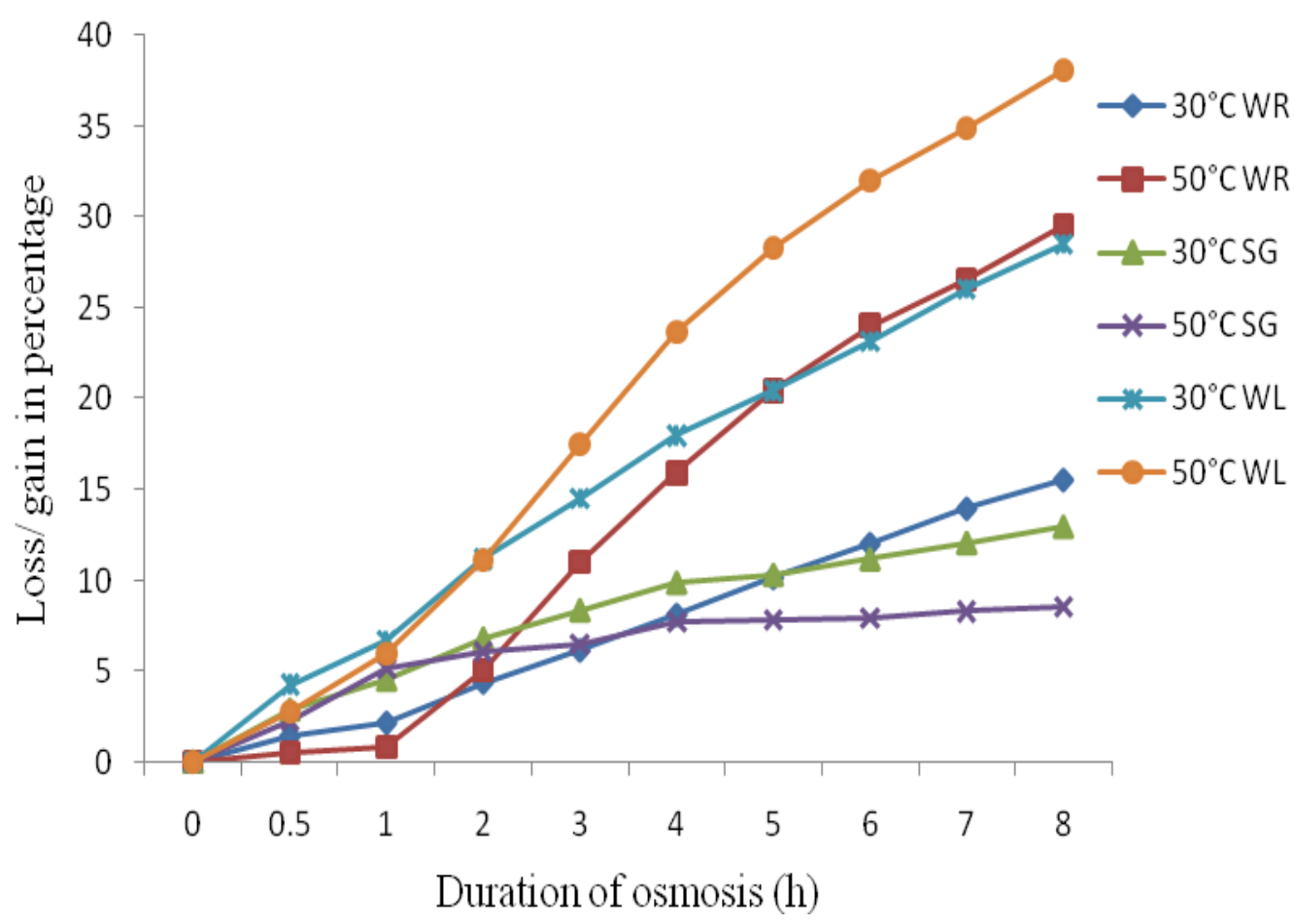

Fig.4 Effect of slice thickness on weight reduction during osmotic dehydration of apple

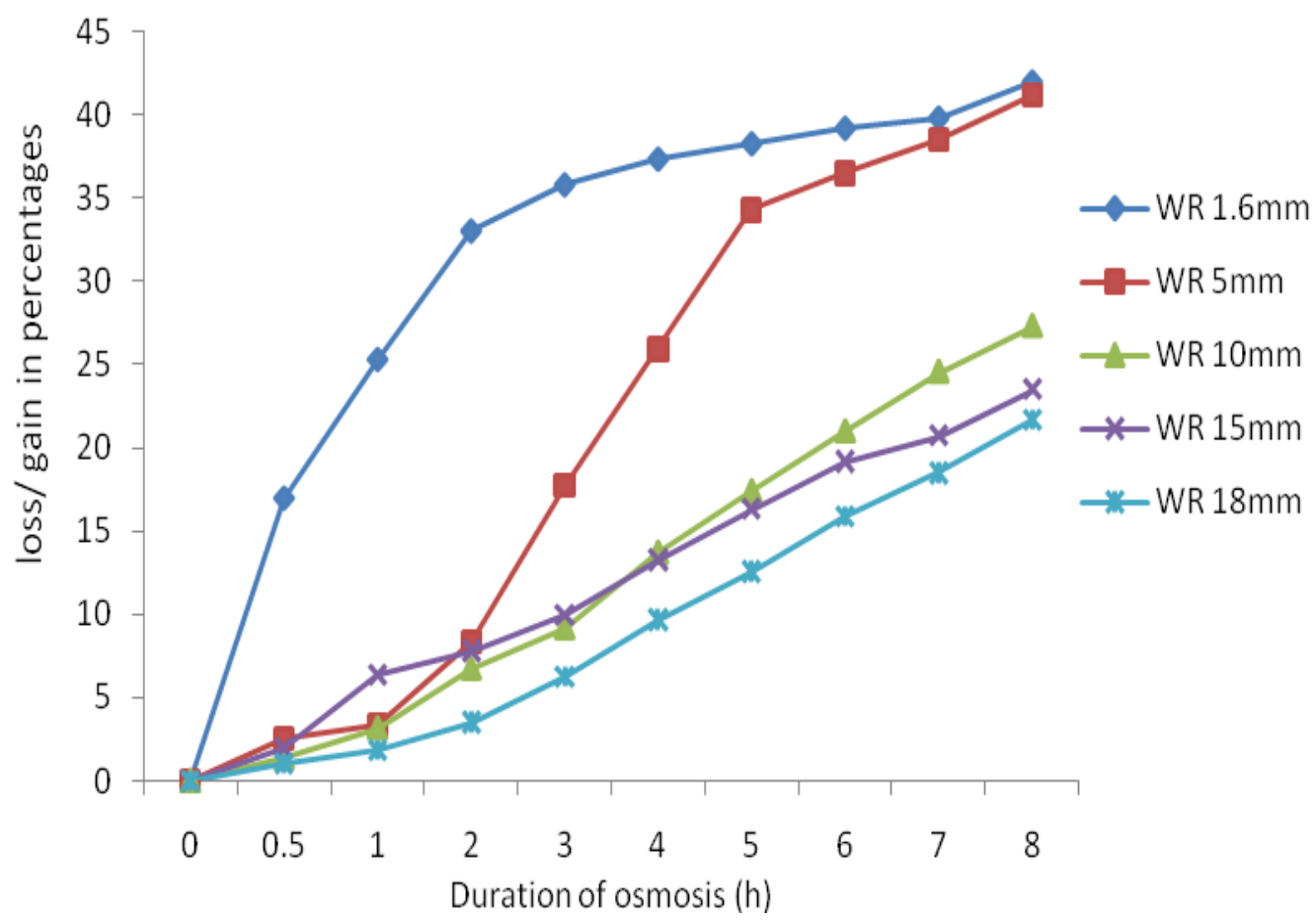


Fig.5 Effect of slice thickness on solid gain during osmotic dehydration of apple

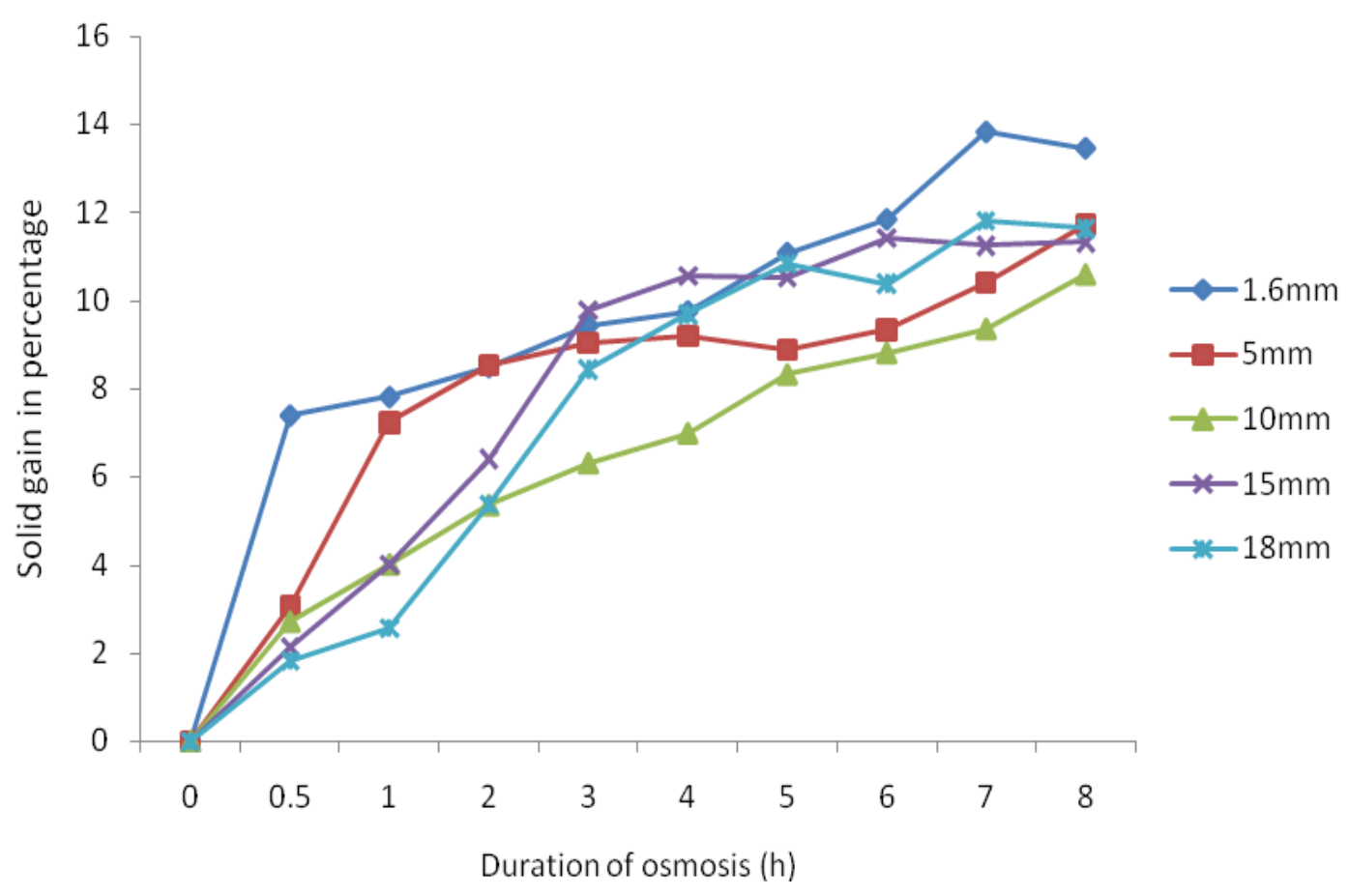

Fig.6 Effect of slice thickness on water loss during osmotic dehydration of apple

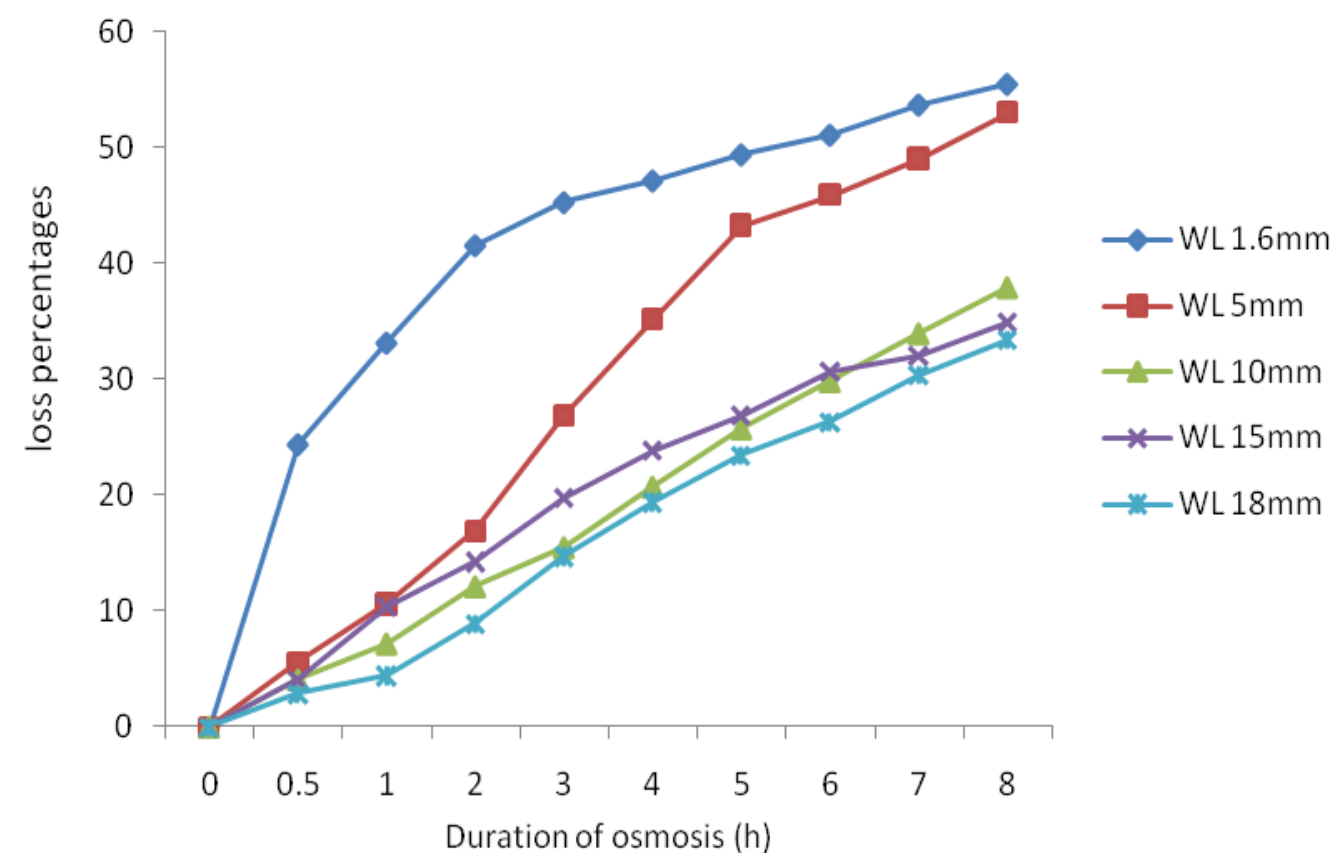


Fig.7 Effect of temperature on moisture content of apple

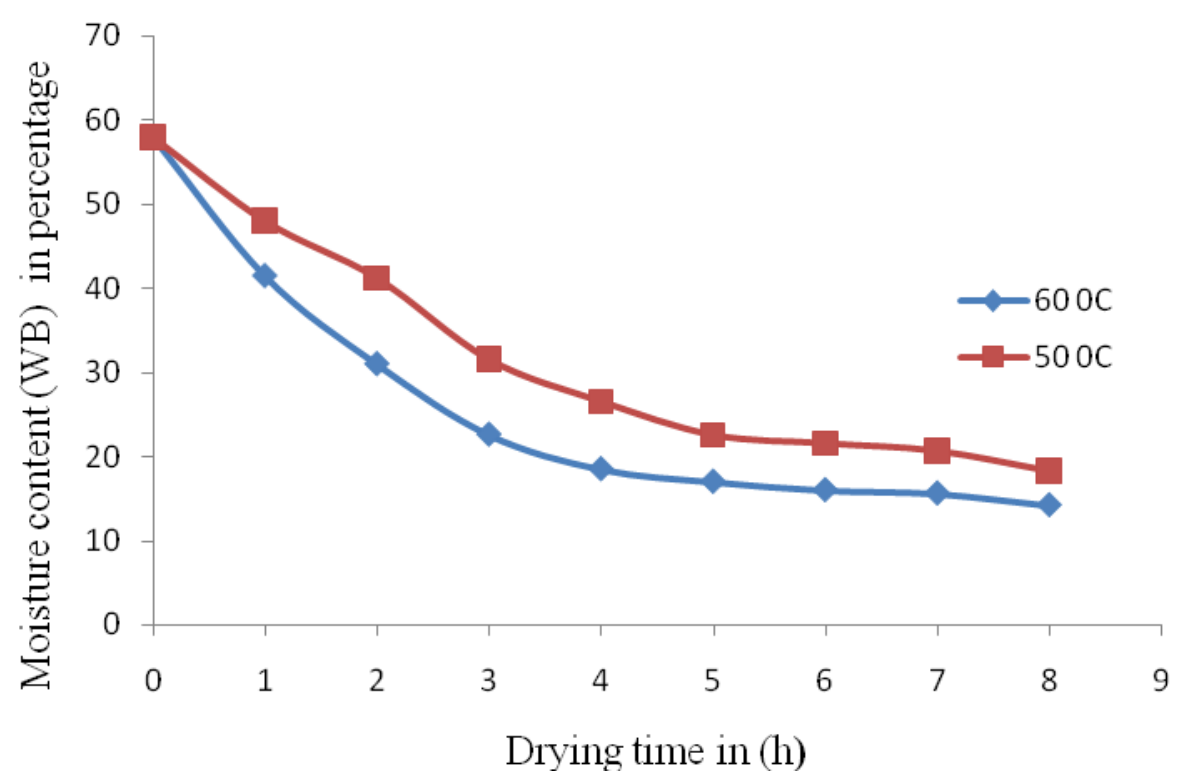

The value of SG decreases as WR and WL increases. Highest value was SG was $12.97 \%$ at $30{ }^{\circ} \mathrm{C}$ and lowest value was $8.56 \%$ at 50 ${ }^{\circ} \mathrm{C}$. From the observation it was concluded that, the osmotic dehydration is the two way mass transfer processes and it is affected by processed temperature and time of immersion (Farkas and Lazar, 1969; Hope and Vital, 1972; Beristain et al., 1990 and Alam et al., (2013)). Temperature can be one of the advantageous factors to complete osmotic dehydration rapidly but same time higher temperature affects colour and flavor of product.

\section{Effect of slices thickness on osmotic dehydration characteristics of apple slices}

The effect of slice thickness on WR, WL and SG is shown in Figure 4, 5 and 6 respectively. The WR was much faster in case of $1.6 \mathrm{~mm}$ slice and this trend was followed by $5 \mathrm{~mm}$ thickness apple fruit slices. It was also observed that slice with more thickness, greatly reduced the SG, WR and WL. All three parameters were least when $18 \mathrm{~mm}$ slices were used for osmotic dehydration. It was also observed that the dehydration rate decreased with the increase in slice thickness.

\section{Drying of osmotic dehydrated apple slices}

The osmotically dehydrated apple slices for 8 $\mathrm{h}$ in sugar solution of $70^{\circ} \mathrm{B}$ at temperature of $50^{\circ} \mathrm{C}$ were dried in tray dryer at $60^{\circ} \mathrm{C}$ and 50 ${ }^{\circ} \mathrm{C}$ temperature for $8 \mathrm{~h}$. The moisture content was measured at different drying time intervals and data were analyzed. The effect of drying temperature on moisture content is shown in Figure 7. It was observed that drying rate was faster in case of $\quad 60^{\circ} \mathrm{C}$ as compare to $50{ }^{\circ} \mathrm{C}$ and after $5 \mathrm{~h}$ of drying the moisture content is almost constant for both $60{ }^{\circ} \mathrm{C}$ and $50^{\circ} \mathrm{C}$ temperature. The weight reduction was more rapid in first $4 \mathrm{~h}$ after that drying rate gradually decreased and almost reached constant.

The drying of osmotic dehydrated apple slices was done at different temperature of $50{ }^{\circ} \mathrm{C}$ and $60^{\circ} \mathrm{C}$ using cabinet dryer for $8 \mathrm{~h}$. Initially the apple slices were dehydrated osmotically 
for $8 \mathrm{~h}$ at $30{ }^{\circ} \mathrm{C}$ and $50{ }^{\circ} \mathrm{C}$ by different concentrations of sugar solution. The osmotically treated apple slices were dried in tray dryer upto the moisture level of $14 \%$. During osmotic dehydration the maximum value of WL, WR and SG was found to be $62.9 \%, 52.0 \%$, and $11.2 \%$ for $70{ }^{\circ} \mathrm{B}$ with 1.6 $\mathrm{mm}$ thick apple slice whereas the minimum value was $52.9 \%, 41.21 \%$ and $10.50 \%$ for $50^{\circ} \mathrm{B}$ with $18 \mathrm{mmrespectively} \mathrm{after} 8 \mathrm{~h}$ of osmosis. The maximum WL and WR was found to $38.07 \%$ and $29.1 \%$ at $50{ }^{\circ} \mathrm{C}$ whereas lowest value was $28.5 \%$ and $15.5 \%$ at $30{ }^{\circ} \mathrm{C}$ respectively after 8 hour of osmotic dehydration of apple slices. The value of SG decreases as WR and WL increases. Highest value was $\mathrm{SG}$ was reported to $12.97 \%$ at 30 ${ }^{\circ} \mathrm{C}$ and lowest value was $8.56 \%$ at $50{ }^{\circ} \mathrm{C}$. From the study it was concluded that solution concentration, sample immersion time and solution temperature and thickness of slices were the most prominent factors which affects the solid gain, water loss and moisture loss during osmotic dehydration of apple slices. By processing of apple fruit post-harvest losses during handling and storage can be reduced, its self-life, product quality and market value can be maximized.

\section{References}

Beristain, C.I., Azuara, E., Cortes, R. and Garcia, H.S., 1990. Mass transfer during osmotic dehydration of pineapple. International Journal of Food Science Technology, 8: 122-130.

Chiralt, A. and Talens, P. 2005. Physical and chemical changes induced by osmotic dehydration in plant tissues. Journal of Food Engineering, 67: 167-177.

Conway, J., Castaigne, F., Picard, G., \& Vevan, X. (1983). Mass transfer considerations in osmotic dehydration of apples. Canadian International Food Science and Technology Journal, 16(1), $25-29$.
Dermesonlouoglou, E.K., Giannakourou, M.C., Bakalis, S. and Taoukis, P.S. 2005. Mass transport properties of watermelon tissue in osmotic solutions and effect of osmotic dehydration on frozen watermelon quality. Acta Horticulture, 674: 481-487.

Dixon G.M., Jen J.J. and Paynter V.A. 1976. Tasty apples slices results from combined osmotic - dehydration and vacuum drying process. Food Product Development, 10(7): 60-64.

Ertekin, F. K., \& Cakaloz, T. (1996). Osmotic dehydration of peas: Influence of process variables on mass transfer. Journal of Food Processing and Preservation, 20, 87-95.

Fernandes FA, Rodrigues S, Gaspareto OC, and Oliveira EL (2006). Optimization of osmotic dehydration of papaya followed by air-drying. Food Research International, 39(4): 492-498.

Gourav Sahu, N. Vinoda, P. Monisha, Vikas Paradkar and Nirmal Kumar. 2017. Studies on Drying of Osmotically Dehydrated Onion Slices. Int.J. Curr. Microbiol. App. Sci. 6(9): xx-xx. doi: https://doi.org/10.20546/ijcmas.2017.60 9.xx

Hawkes, J., \& Flink, J. M. 1978. Osmotic concentration of fruit slices prior to freeze dehydration. Journal of Food Processing and Preservation, 2, 265284.

Karthanos, V. T., Kastaropoulus, A. E., \& Saravacos, G. D. 1995. Airdrying behaviour of osmotically dehydrated fruits. Drying Technology, 13(5-7), 1503-1506.

Krokida, M.K., Karathanos, V.T. and Maroulis, Z.B. 2000. Effect of osmotic dehydration on colour and sorption characteristics of apple and banana. Drying Technology 18(3-4): 937-950.

Mandala, I.G., Anagnostaras, E.F. and Oikonomou, C.K. 2005. Influence of 
osmotic dehydration conditions on apple air-drying kinetics and their quality characteristics. Journal of Food Engineering, 69: 307-316.

Nieuwenhuijzen, N., Zareifard, M.R. and Rasmaswamy, H.S. 2001. Osmotic drying kinetics of cylindrical apple slices of different sizes. Drying Technology 19: 525-545.

Pokharkar, S. M. (2001). Kinetic model for osmotic dehydration of green peas prior to air-drying. Journal of Food Science and Technology, 38(6), 557-560.

Ranganna, S. 2000. Handbook of analysis and quality control for fruits and vegetable produce, Tata McGraw hill publishing co-operation limited; New Delhi.

Rastogi, N. K., and Raghavarao, K. S. M. S. (1997). Water and solute diffusion coefficients of carrot as a function of temperature and concentration during osmotic dehydration. Journal of Food Engineering, 34, 429-440.

Sodhi, N.S. and Komal, N.S. 2006. Osmotic dehydration kinetics of carrots. Journal of Food Science and Technology 43(4): 374-376.

Spiazzi, E. and Mascheroni, R.H., 1997. Mass Transfer Model for Osmotic Dehydration of Fruits and Vegetables- I. Development of the Simulation Model. J. of Food Engineering, 34: 387-410.

Sutar P.P. and Gupta D.K. 2007. Mathematical modeling of mass transfer in osmotic dehydration of onion slices. Journal of Food Engineering, 78, 90-97

Torreggiani, D. and Bertolo, G. 2001. Osmotic pre-treatments in fruit processing: chemical, physical and structural effects. Journal of Food Engineering, 49: 247-253.

\section{How to cite this article:}

Vikas Paradkar and Gourav Sahu. 2018. Studies on Drying of Osmotically Dehydrated Apple Slices. Int.J.Curr.Microbiol.App.Sci. 7(11): 633-642. doi: https://doi.org/10.20546/ijcmas.2018.711.077 